\title{
Tropical climate induces seasonal changes in the reproductive parameters and hormonal profile of Saanen bucks
}

\author{
Maria G. F. Salles ${ }^{1}$, Aderson M. Viana Neto ${ }^{2 *}$, Maurício F. Vieira Neto ${ }^{3}$, Inti C. S. \\ Rodrigues $^{4}$, David R. da Rocha ${ }^{5}$, Priscila T. de Souza Carneiro ${ }^{6}$, and Airton A. de Araújo ${ }^{2}$ \\ ${ }^{1}$ Institute of Rural Development, University for International Integration of the Afro-Brazilian Lusophony, \\ Redenção, Brazil \\ ${ }^{2}$ Veterinary College, Ceara State University, Fortaleza, Brazil \\ ${ }^{3}$ Morphology Department, Medicine College, Federal University of Ceara, Fortaleza, Brazil \\ ${ }^{4}$ Health Department, Ocara, Brazil \\ ${ }^{5}$ Animal Science Department, Federal University of San Francisco Valley, Petrolina, Brazil \\ ${ }^{6}$ Agricultural and Biodiversity Sciences Center, Federal University of Cariri, Crato, Brazil
}

SALLES, M. G. F., A. M. VIANA NETO, M. F. VIEIRA NETO, I. C. S. RODRIGUES, D. R. DA ROCHA, P. T. DE SOUZA CARNEIRO, A. A. DE ARAÚJO: Tropical climate induces seasonal changes in the reproductive parameters and hormonal profile of Saanen bucks. Vet. arhiv 90, 235-242, 2020.

\section{ABSTRACT}

This study evaluated the effects different seasons (rainy, rainy-dry transition, dry, dry-rainy transition) throughout the year on the reproduction and endocrine profile of Saanen bucks reared in a tropical climate. During these seasons environmental data were recorded (ambient temperature and relative air humidity) to calculate the temperature and humidity index. Reproductive parameters were also evaluated in the same periods to check seasonal variations, wherey semen was collected twice a month from nine Saanen bucks using an artificial vagina. Furthermore, scrotal circumference, scrotal surface temperature and serum levels of testosterone, triiodothyronine (T3), thyroxine (T4) and cortisol were measured. The climate parameters influenced the reproductive parameters, mainly during the dry period, when higher values of ambient temperature reduced sperm quality, however, scrotal circumference and surface temperature, as well as serum levels of testosterone increased. In conclusion, Saanen bucks reared in a tropical climate are subject to heat stress, evinced by transient seasonal variations in reproductive parameters, where the first season is the most favorable to reproduction.

Key words: bucks; reproductive parameters; heat stress; testosterone

\section{Introduction}

Although goats are known for their adaptability to harsh environments, their productivity is affected by extreme weather conditions and they are sensitive to heat stress, even though they are characterized as heat-resistant animals (THOMAS et al., 2015).
Most milk goat breeds reared in Brazil are from Europe (Saanen, Alpine and Toggenburg) where climatic conditions favor the thermoregulation of animals. This is related to the elevated thermal gradient between ambient and skin temperature,

*Corresponding author:

Aderson Martins Viana Neto, Veterinary College, Ceara State University, Fortaleza, Brazil, E-mail: adersonv@gmail.com 
and the goat's adaptability that facilitates body heat adjustment (GUPTA and MONDAL, 2019). In tropical climates these animals are subject to a challenging environmental situation, leading to changes in physiological thermoregulatory responses, which may decrease fertility and testicular function, decreasing reproductive performance as a result of the high ambient temperature heating the testes (DE et al., 2014; KASTELIC et al., 2014). Associated to this, the limited blood flow results in hypoxia and testicular degeneration, characterized by disturbance or disruption of spermatogenesis, caused by atrophy of the seminal epithelium (PAUL et al., 2009), leading to a reduction in male fertility (RASOOLI et al., 2010).

Studies on male endocrinology describe the role of several hormones on the regulation of sexual behavior, by characterizing their influence or quantifying their concentrations, seeking to predict the sexual performance potential of male goats (BELKADI et al., 2017; DE et al., 2017). Saanen bucks in Northeastern Brazil are submitted to thermal stress due to climatic variation in different seasons of the year, that affect their reproductive efficiency. Thus, this study aimed to evaluate the reproductive parameters and serum levels of testosterone, triiodothyronine (T3), thyroxine (T4) and cortisol of Saanen bucks reared in a tropical climate.

\section{Materials and methods}

Local and animals. The study was carried out at Pacatuba - Ceara/BRA (3 ${ }^{\circ} 53^{\prime} 49,9$ 'S, $\left.38^{\circ} 34^{\prime} 32,5^{\prime \prime} \mathrm{W}\right)$. The climate is hot and humid, with an average annual temperature of $28^{\circ} \mathrm{C}$. Nine Saanen bucks $(67.1 \pm 14.2 \mathrm{~kg} ; 3.4 \pm 1.9$ years $)$ were reared in an intensive system and fed with a concentrate containing $22 \%$ crude protein and green forage $(70 \%$ Pennisetum purpureum Schum plus $30 \%$ Leucaena leucocephala), and water ad libitum. All the animals were managed in accordance with the International Guiding Principles for Biomedical Research Involving Animals.

Seasons and climatic parameters. In order to determine the climatic parameters, the year was divided into four seasons according to the rainfall index, in accordance with FUNCEME: 1) rainy:
February to May; 2) rainy-dry transition: June and July; 3) dry: August to November; 4) dry-rainy transition: December and January. Climatic data of ambient temperature (AT) and relative humidity (RH) were collected using a digital thermohygrometer (Incoterm ${ }^{\circledR}$, Porto Alegre, Brazil).

These data were used to estimate the temperature and humidity index (THI):

$\mathrm{THI}=(0.8 \times \mathrm{AT}+(\mathrm{RH} \div 100) \times(\mathrm{AT}-14.4)+46.4)$ (according to Thom, 1959)

where: $\mathrm{AT}=$ ambient temperature $\left({ }^{\circ} \mathrm{C}\right), \mathrm{RH}=$ relative humidity $(\%)$.

Semen collection and analysis. The reproductive parameters of nine fertile male goats were evaluated twice a month, in the morning. Scrotal circumference and surface temperature were measured using a flexible metal measuring tape and a digital infrared thermometer $1 \mathrm{~cm}$ from the scrotal skin, respectively. Semen was collected using an artificial vagina coupled to a graded conical tube $(15 \mathrm{~mL})$ and employing an estrogen-induced estrus goat (Estrogin ${ }^{\circledR}$, Biofarm, Jaboticabal, Brazil). Immediately after collection, the volume was measured using a graduated conical tube. Sperm concentration, mass motility, individual sperm progressive motility, percentage of motile sperm, and sperm pathologies were evaluated according to the Brazilian College of Animal Reproduction (CBRA, 2013) standards, by an experienced and well-trained evaluator in light-microscopy. During semen collection, the reaction time was observed, that is, the time from the buck's introduction to the collection pen to ejaculation (mount with vaginal intromission).

Blood sampling and immunoassay. For hormonal analysis, blood samples were collected every 15 days (total: 24 blood samples for each animal) by jugular venipuncture into heparinized evacuated tubes $(10 \mathrm{~mL})$ and immediately centrifuged at $3,000 \mathrm{rpm}$ for 15 minutes. Plasma collected was stored in microtubes at $-20{ }^{\circ} \mathrm{C}$ until determination of testosterone, free triiodothyronine (T3), free thyroxine (T4) and cortisol. All the samples from each buck were measured in duplicate by microparticle enzyme immunoassay methodology (MEIA) in AxSYM equipment (Abbott, Abbott Park, Illinois, USA). The results of testosterone 
M. G. F. Salles et al.: Tropical climate induces seasonal changes in the reproductive parameters and hormonal profile of Saanen bucks

(3C85-20) were expressed in $\mathrm{ng} / \mathrm{mL}$, of free $\mathrm{T} 3$, in $\mathrm{pg} / \mathrm{mL}$, of free $\mathrm{T} 4$, in $\mathrm{ng} / \mathrm{dL}$ and of cortisol, in $\mu \mathrm{g} /$ $\mathrm{dL}$. The AxSYM assay for testosterone showed a functional sensitivity $\leq 0.2 \mathrm{ng} / \mathrm{mL}$ and an analytical sensitivity $\leq 0.1 \mathrm{ng} / \mathrm{mL}$, with no significant carryover smaller than the functional sensitivity: in the free $\mathrm{T} 3$, sensitivity $\geq 1.1 \mathrm{pg} / \mathrm{mL}$ and $0.001 \%$ specificity with carryover $\leq 1 \%$; in the free $\mathrm{T} 4$, sensitivity of $0.4 \mathrm{ng} / \mathrm{dL}$ and specificity $<0.5 \%$ for L-T3, and $100 \%$ for D-T4; and for cortisol, an analytical sensitivity of approximately $0.2 \mu \mathrm{g} / \mathrm{dL}$.

\section{Results}

Climatic parameters. Ambient temperature throughout the year showed higher values in the dry season $\left(31.3 \pm 0.07{ }^{\circ} \mathrm{C}\right)$. Nevertheless, relative humidity and rainfall were higher during the rainy
Data analysis. Statistical analysis was performed to calculate mean and standard errors of the mean for climate data, seminal parameters and blood level of testosterone, T3, T4 and cortisol of male goats over different seasons. Analysis of variance was performed through the GLM model using the Systat v.12 software (Systat Software, San Jose, CA) to evaluate seasonal effects on reproductive parameters and hormonal levels. Mean values were compared by Tukey's test (pairwise comparison) with $5 \%$ probability of error.

season $(70.8 \% ; 595.9 \mathrm{~mm})$. Thus, the temperature and humidity indexes (THI) were higher in the rainy season than in the dry season (80.6; Fig. 1).

Table 1. Climatic parameters of experimental period, reproductive parameters and hormonal serum levels of Saanen bucks reared in a tropical climate (Mean $\pm \mathrm{SE}$ )

\begin{tabular}{|c|c|c|c|c|}
\hline Parameters & Rainy season & Rainy-dry transition & Dry season & Dry-rainy transition \\
\hline \multicolumn{5}{|l|}{ Climatic parameters } \\
\hline Ambient temperature $\left({ }^{\circ} \mathrm{C}\right)$ & $29.4 \pm 0.07$ & $29.4 \pm 0.09$ & $31.3 \pm 0.07$ & $30.2 \pm 0.09$ \\
\hline Relative humidity (\%) & $70.8 \pm 0.49^{\mathrm{a}}$ & $53.7 \pm 0.66^{\mathrm{b}}$ & $33.0 \pm 0.40^{\mathrm{b}}$ & $41.3 \pm 0.90^{\mathrm{b}}$ \\
\hline Temperature and humidity Index & $80.6 \pm 0.12^{\mathrm{a}}$ & $78.0 \pm 0.12^{\mathrm{b}}$ & $76.9 \pm 0.08^{b}$ & $76.9 \pm 0.11^{\mathrm{b}}$ \\
\hline Rainfall $(\mathrm{mm})$ & $595.9 \pm 117.9^{\mathrm{a}}$ & $97.5 \pm 70^{b}$ & $3.2 \pm 1.8^{\mathrm{c}}$ & $63.2 \pm 56^{\mathrm{b}}$ \\
\hline \multicolumn{5}{|l|}{ Reproductive parameters } \\
\hline Libido (s) & $22.1 \pm 2.6^{\mathrm{b}}$ & $38.2 \pm 8.4^{\mathrm{ab}}$ & $55.4 \pm 10^{\mathrm{a}}$ & $41.4 \pm 6.9^{\mathrm{ab}}$ \\
\hline Scrotal circumference $(\mathrm{cm})$ & $29.7 \pm 0.2^{c}$ & $31.5 \pm 0.3^{\mathrm{b}}$ & $32.5 \pm 0.3^{\mathrm{a}}$ & $31.0 \pm 0.3^{\mathrm{b}}$ \\
\hline Scrotal surface temperature & $30.7 \pm 0.2^{c}$ & $31.6 \pm 0.1^{\mathrm{b}}$ & $32.1 \pm 0.1^{\mathrm{a}}$ & $31.3 \pm 6.4^{\mathrm{b}}$ \\
\hline Volume $(\mathrm{mL})$ & $1.63 \pm 0.08^{\mathrm{ab}}$ & $1.33 \pm 0.12^{b}$ & $1.52 \pm 0.14^{b}$ & $1.91 \pm 0.07^{\mathrm{a}}$ \\
\hline Mass motility & $2.68 \pm 0.21$ & $2.79 \pm 0.40$ & $3.13 \pm 1.12$ & $2.20 \pm 0.23$ \\
\hline Individual sperm progressive motility & $3.74 \pm 0.90$ & $3.87 \pm 0.95$ & $3.31 \pm 1.1$ & $2.37 \pm 0.23$ \\
\hline Percentage of motile sperm & $54 \pm 4.2^{\mathrm{a}}$ & $50 \pm 5.8^{\mathrm{a}}$ & $30 \pm 4.5^{\mathrm{b}}$ & $33 \pm 3.3^{b}$ \\
\hline Sperm concentration $\left(10^{9} \mathrm{sperm} / \mathrm{mL}\right)$ & $2.3 \pm 0.13^{\mathrm{a}}$ & $1.8 \pm 0.19^{\mathrm{b}}$ & $1.9 \pm 0.09^{\mathrm{b}}$ & $1.6 \pm 0.09^{\mathrm{b}}$ \\
\hline Sperm pathologies (\%) & $31 \pm 3.8^{\mathrm{b}}$ & $36 \pm 4.2^{\mathrm{ab}}$ & $45 \pm 3.6^{\mathrm{a}}$ & $33 \pm 2.2^{\mathrm{ab}}$ \\
\hline \multicolumn{5}{|l|}{ Hormonal serum levels } \\
\hline Testosterone $(\mathrm{ng} / \mathrm{mL})$ & $5.62 \pm 0.57^{\mathrm{b}}$ & $2.81 \pm 0.64^{\mathrm{c}}$ & $7.33 \pm 0.97^{\mathrm{a}}$ & $8.99 \pm 1.26^{\mathrm{a}}$ \\
\hline $\mathrm{T} 3(\mathrm{pg} / \mathrm{mL})$ & $2.0 \pm 0.11^{\mathrm{a}}$ & $1.97 \pm 0.16^{\mathrm{a}}$ & $1.97 \pm 0.14^{\mathrm{a}}$ & $1.47 \pm 0.14^{\mathrm{b}}$ \\
\hline $\mathrm{T} 4$ (ng/dL) & $0.84 \pm 0.02$ & $0.80 \pm 0.04$ & $0.74 \pm 0.03$ & $0.94 \pm 0.09$ \\
\hline Cortisol $(\mu \mathrm{g} / \mathrm{mL})$ & $1.08 \pm 0.03^{\mathrm{c}}$ & $1.36 \pm 0.04^{\mathrm{b}}$ & $1.43 \pm 0.04^{\mathrm{b}}$ & $2.9 \pm 0.02^{\mathrm{a}}$ \\
\hline
\end{tabular}

Different letters in the same row indicate significant differences $(\mathrm{P}<0.05)$ by Tukey's test 
Seminal parameters. The semen characteristics of Saanen bucks showed the greatest ejaculate volume during the dry-rainy transition season $(1.91$ $\mathrm{mL} ; \mathrm{P}<0.05$ ), while the mass motility (mean: 2.7 ) and individual sperm progressive motility (mean: 3.3) demonstrated no differences between the periods (Table 1).

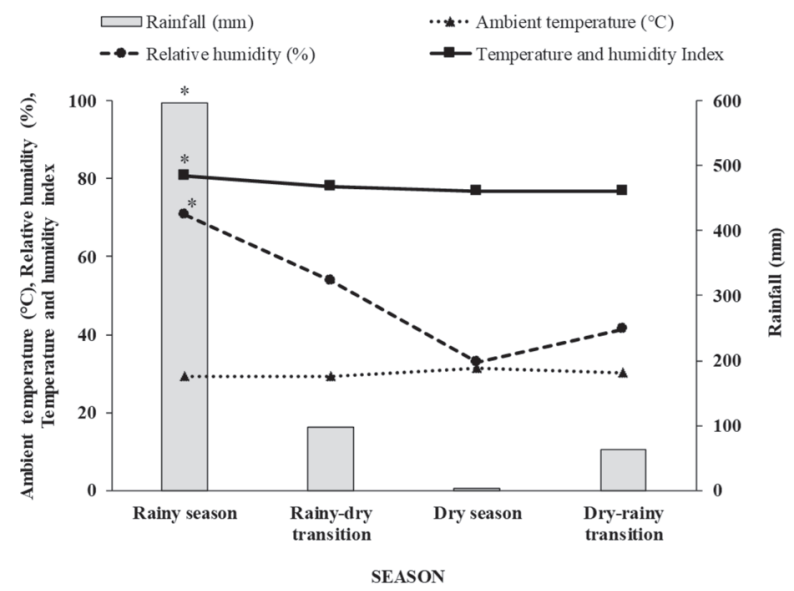

Fig. 1. Climatic parameters (mean $\pm \mathrm{SE}$ and maximum values) during evaluation of the reproduction and endocrine profile of Saanen bucks at Pacatuba, Ceara, Brazil. *Significant differences $(\mathrm{P}<0.05)$ between seasons by Tukey's test.

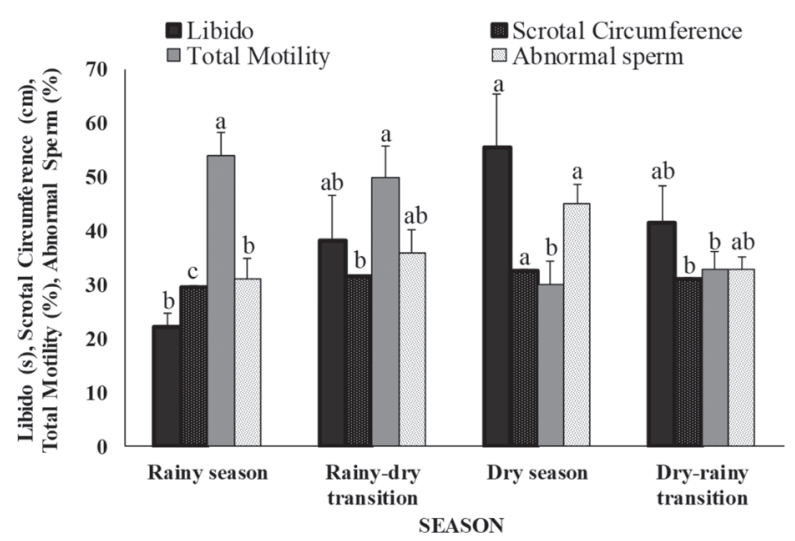

Fig. 2. Libido (seg), scrotal circumference (cm), total motility (\%) and abnormal sperm (\%) of Saanen bucks reared in a tropical climate.

The percentage of motile sperm showed higher results in first half-year (52 vs. 31.5\%; $\mathrm{P}<0.05$ ). During the rainy season, the lowest ambient temperature increased testis thermoregulation and sperm concentration $\left(2.3 \times 10^{9} \mathrm{sperm} / \mathrm{mL}\right.$; $\mathrm{P}<0.05)$. Higher values of ambient temperature in the second half-year increased the percentage of morphologically abnormal sperm in the dry season $(45 \pm 3.6 \%)$ compared to the rainy season $(31 \pm$ $3.8 \%$; $\mathrm{P}<0.05$; Fig. 2).

The reaction time to female in estrus (libido) was longer in the dry season $(55.4 \pm 10 \mathrm{~s}$; high temperatures) and shorter in the rainy season (22.1 \pm $2.6 s ; \mathrm{P}<0.05$; Fig. 2). This also occurred in relation to scrotal surface temperature, that was higher in the dry season $\left(32.1 \pm 0.1{ }^{\circ} \mathrm{C}\right)$ and lower in the rainy season $\left(30.7 \pm 0.2{ }^{\circ} \mathrm{C} ; \mathrm{P}<0.05\right)$. In contrast, the largest scrotal circumference was registered in the dry season $(32.5 \pm 0.3 \mathrm{~cm})$, while the smallest was measured when the ambient temperature was lower $(29.7 \pm 0.2 \mathrm{~cm} ; \mathrm{P}<0.05)$.

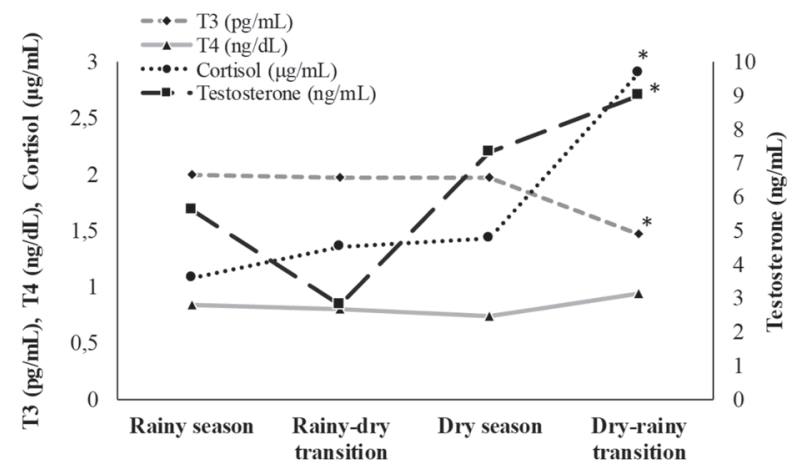

SEASON

Fig. 3. Serum levels of testosterone, triiodothyronine (T3), thyroxine (T4) and cortisol of Saanen bucks reared in a tropical climate. *- Significant differences $(\mathrm{P}<0.05)$ between seasons by Tukey's test.

Hormonal profile. Hormonal parameters are shown in Fig. 3. Testosterone presented threshold levels in the transition periods, and the lowest in the rainy-dry transition $(2.81 \pm 0.64 \mathrm{ng} / \mathrm{mL})$ and the highest level in the dry-rainy transition $(8.99 \pm$ $1.26 \mathrm{ng} / \mathrm{mL} ; \mathrm{P}<0.05)$. T3 serum levels decreased, while cortisol levels were higher during the dryrainy transition season (T3: $1.47 \pm 0.14 \mathrm{pg} / \mathrm{mL}$; Cortisol: $2.9 \pm 0.02 \mu \mathrm{g} / \mathrm{mL}$; $\mathrm{P}<0.05)$. Nonetheless, $\mathrm{T} 4$ levels did not alter over the year $(0.83 \pm 0.03 \mathrm{ng} /$ $\mathrm{dL} ; \mathrm{P}>0.05$ ).

\section{Discussion}

Climatic parameters. The climatic parameters were characterized as a tropical climate so that Saanen bucks are reared at risk of thermal stress 
during the year in this region (RIBEIRO et al., 2018). Moreover, during the dry season the environmental conditions are less severe which facilitates heat dissipation to maintain homeostasis because of lower relative humidity, despite the higher ambient temperature. During the rainy season an emergency condition was verified caused by maximum THI values, when the ambient temperature and relative humidity were high, causing thermal discomfort (BERMAN et al., 2016).

Seminal parameters. Seminal parameters of Saanen male goats were higher in the first half year. However, they were considered low values for Saanen bucks indicating that in this climate these animals are negatively affected, regardless of the season. Moreover, the percentage of morphologically abnormal sperm was high throughout the year, showing that Saanen bucks are affected all year long, when reared in a tropical climate. In environments where THI is outside the thermoneutral zone, testis thermoregulation is insufficient, increasing the number of pathologies and interfering with seminal parameters (DE et al., 2017; KASTELIC et al., 2014).

The reproductive parameters of goats vary between breeds and the climates where they are reared. Considering the semen volume of Saanen bucks, the study found higher values than the $1.15 \mathrm{~mL}$ reported by WANG et al. (2015). Nonetheless, the mass and individual sperm motility over a year were similar to DIAS et al. (2017). Sperm concentration was higher when ambient temperatures were lower, as found by SUHAIR and ABDALLA (2013). As observed by SALIM ELSHEIKH et al. (2015), during warm periods there was an increase in morphologically abnormal spermatozoa, but EL KADILI et al. (2019) reported the greatest sperm normality in the summer. Therefore, thermal stress may cause temporary disruption of sperm production and increase abnormalities, affecting the reproductive efficiency of male goats (ELOY and PEREIRA, 2013).

The largest scrotal circumference during the dry season is related to the contraction and distension of the tunica dartos and cremaster muscles that regulate testis position, allowing their better thermoregulation, and consequently a lower scrotal surface temperature (DURAIRAJANAYAGAM et al., 2015).

Furthermore, male goat exposure to high air temperatures increases the percentage of sperm abnormalities in their semen (SALIM ELSHEIKH et al., 2015), which was also found in this study. When the scrotal temperature decreased scrotum contraction occurs so that if the temperature increases, distension and the largest scrotal circumference may be observed. In adult fat-tailed rams, HEDIA et al. (2019) also found the highest scrotal circumference values during warmer months. Scrotal temperature depends on metabolic heat production, scrotal circulation (pampiniform plexus) and the environment, aided by scrotal sweat glands (DURAIRAJANAYAGAM et al., 2015).

Hormonal profile. Serum T3 and cortisol levels were affected by the ambient temperature and relative humidity so that during heat stress there was rapid cortisol release, and a longer latency period of thyroid hormones. The lower T3 levels and higher cortisol levels in December and January, indicating THI at alert or emergency levels, evince the thermal stress which Saanen male goats are subject to in a tropical climate.

Studies report the impact of heat stress on testosterone secretion in breeding animals, as it reduces testis blood flow and testosterone blood levels (HEDIA et al., 2019). Meanwhile, there is also report suggesting stress alone is not responsible for inhibiting testis activity (BHATTA et al., 2015). Additionally, serum testosterone levels could increase in the initial stages of acute stress, and their variations are not always associated with male reproductive activity (WINGFIELD and SAPOLSKY, 2003). High temperatures have deleterious effects on spermatogenesis, but testicular apoptosis induced by thermal stress acts through a physiological mechanism independent from that observed under induced depletion of testosterone levels. Heat stress produced by different techniques affected testicular cells differently, so that Leydig cells and androgen production could be directly affected (PAUL et al., 2009).

DIAS et al. (2017) demonstrated testosterone levels increased even if LH levels were constant or reduced in Alpine bucks. Thus, a decrease in LH 
levels could not influence testis activity, so that serum testosterone levels should not be used as a parameter of breeding soundness in male goats under heat stress. COELHO et al. (2008) found that bucks under heat stress presented no changes in testosterone levels, but a discrete variation according to breed, being higher in Saanen than Alpine male goats. Moreover, testosterone level changes could be independent of seminal parameters (such as sperm concentration and abnormal sperm; BELKADI et al., 2017).

Our results are according to HABIBU et al. (2017) who claimed that thermal stress is responsible for serum thyroid hormone reduction, and RIBEIRO et al. (2018) who observed lower T3 and T4 levels during the dry season in Brazilian creole goats. Furthermore, T3 induces the synthesis of soluble protein in Leydig cells, which stimulates androgen release (WAGNER et al., 2008).

The direct exposure of males to high ambient temperatures could increase cortisol secretion, without any significant effect on testosterone production (RASOOLI et al., 2010). In goats, heat stress increases serum cortisol levels, mainly after acute heat stress (HOOPER et al., 2018). The use of thyroid hormones and cortisol levels as heat stress indicators facilitates and understanding of the physiological mechanisms' relationship to thermolysis and homeothermy (RIBEIRO et al., 2016).

\section{Conclusions}

Therefore, Saanen bucks reared in a tropical climate showed a transient impairment of semen quality in the second half-year, where the dry-rainy transition and rainy seasons were most suitable as breeding seasons. Moreover, the reproductive parameters and hormonal level results obtained in tropical environments demonstrate Saanen male goats' sensitivity to heat stress. Thereby, this goat breed requires suitable management for the best reproductive efficiency and genotype expression.

\section{Conflicts of interest}

The authors declare that they have no conflicts of interest.

\section{References}

BELKADI, S., B. SAFSAF, N. HELEILI, M. TLIDJANE, L. BELKACEM, Y. OUCHERIAH (2017): Seasonal influence on sperm parameters, scrotal measurements, and serum testosterone in Ouled Djellal breed rams in Algeria. Veterinary World. 10, 1486-1492.

DOI: 10.14202/vetworld.2017.1486-1492

BERMAN, A., T. HOROVITZ, M. KAIM, H. GACITUA (2016): A comparison of THI indices leads to a sensible heat-based heat stress index for shaded cattle that aligns temperature and humidity stress. Int. J. Biometeorol. 60, 1453-1462.

DOI: $10.1007 / \mathrm{s} 00484-016-1136-9$

BHATTA, M., D. DAS, P. R. GHOSH (2015): The influence of seasonal variation on the testosterone hormone of black Bengal bucks (Capra aegagrus hircus). Indian J. Biol. 2, 111-115.

DOI: $10.21088 / \mathrm{ijb} .2394 .1391 .2215 .2$

CBRA - Brazilian College of Animal Reproduction (2013): Manual for andrological assessment and evaluation of animal semen (in Portuguese). $3^{\text {rd }}$ ed. Belo Horizonte, MG: CBRA.

COElho, L. A., A. SASA, S. D. BICUdO, J. C. C. BALIEIRO (2008): Plasma concentrations of testosterone, triiodothyronine (T3) and thyroxine (T4) in goats submitted to caloric stress. Arq. Bras. Med. Veterinária e Zootec. 60, 1338-1345 (in Portuguese).

DOI: 10.1590/S0102-09352008000600007

DE, K., D. KUMAR, A. K. SINGH, A. SAHOO, S. M. K. NAQVI (2014): Seasonal variation of physiological response in ewes of farmers' flocks under semi-arid tropical environment. Biol. Rhythm. Res. 45, 397-405.

DOIः 10.1080/09291016.2013.830509

DE, K., D. KUMAR, K. BALAGANUR, V. K. SAXENA, P. THIRUMURUGAN, S. M. K. NAQVI (2017): Effect of thermal exposure on physiological adaptability and seminal attributes of rams under semi-arid environment. J. Therm. Biol. 65, 113-118.

DOI: $10.1016 /$ j.jtherbio.2017.02.020

DIAS, J. C. O., C. M. VEloso, M. C. R. SANTOS, C. T. S. A. M. OLIVEIRA, C. O. SILVEIRA, E. IGLESIAS, P. P. MAITAN, L. M. P. SANGLARD (2017): Seasonal variation in the reproductive activity of male goats raised under tropical climate conditions. R. Bras. Zootec. 46, 192201.

DOI: $10.1590 /$ S1806-92902017000300003

DURAIRAJANAYAGAM, D., A. AGARWAL, C. ONG (2015): Causes, effects and molecular mechanisms of testicular heat stress. Reprod. Biomed. Online. 30, 14-27. DOI: 10.1016/j.rbmo.2014.09.018 
EL KADILI, S., M. RAES, J. BISTER, B. ARCHA, M. CHENTOUF, N. KIRSCHVINK, (2019): Effect of season on sexual behavior, testicular measurements and seminal characteristics in "Beni arouss" North Moroccan bucks. Anim. Reprod. Sci. 201, 41-54.

DOI: 10.1016/j.anireprosci.2018.12.007

ELOY, A. M. X., E. P. PEREIRA (2013): Stress on male goat reproduction. Rev. Bras. Rep. Anim. 37, 156-163 (in Portuguese).

GUPTA, M., T. MONDAL (2019): Heat stress and thermoregulatory responses of goats: a review. Biol. Rhythm Res. 1-27.

DOI: $10.1080 / 09291016.2019 .1603692$

HABIBU, B., M. U. KAWU, T. ALUWONG, H. J. MAKUN (2017): Influence of seasonal changes on physiological variables, haematology and serum thyroid hormones profile in male Red Sokoto and Sahel goats. J. Appl. Anim. Res. 45, 508-516.

DOI: $10.1080 / 09712119.2016 .1220384$

HEDIA, M. G., M. S. EL-BELELY, S.T. ISMAIL, A. M. A. EL-MAATY (2019): Monthly changes in testicular blood flow dynamics and their association with testicular volume, plasma steroid hormones profile and semen characteristics in rams. Theriogenology 123, 68-73.

HOOPER, H. B., P. SANTOS SILVA, S. A. OLIVEIRA, G. K. F. MERIGHE, J. A. NEGRÃO (2018): Acute heat stress induces changes in physiological and cellular responses in Saanen goats. Int. J. of Biom. 62, 2257-2265

DOI: $10.1007 / \mathrm{s} 00484-018-1630-3$

KASTELIC, J. P (2014): Understanding and evaluating bovine testes. Theriogenology $81,18-23$.

DOI: $10.1016 / j$.theriogenology.2013.09.001

PAUL, C., S. TENG, P. T. K. SAUNDERS (2009): A single, mild, transient scrotal heat stress causes hypoxia and oxidative stress in mouse testes, which induces germ cell death. Biol. Reprod. 80, 913-919.

DOI: 10.1095/biolreprod.108.071779

RASOOLI, A., M. T. JALALI, M. NOURI, B. MOHAMMADIAN, F. BARATI (2010): Effects of chronic heat stress on testicular structures, serum testosterone and cortisol concentrations in developing lambs. Anim. Reprod. Sci. 117, 55-59.

DOI: 10.1016/j.anireprosci.2009.03.012
RIBEIRO, N. L., R. G. COSTA, E. C. PIMENTA FILHO, M. N. RIBEIRO, A. CROVETTI, E. P. SARAIVA, R. BOZZI (2016). Adaptive profile of Garfagnina goat breed assessed through physiological, haematological, biochemical and hormonal parameters. Small Rumin. Res. 144, 236-241.

DOI: 10.1016/j.smallrumres.2016.10.001

RIBEIRO, N. L., R. G. COSTA, E. C. PIMENTA FILHO, M. N. RIBEIRO, R. BOZZI (2018): Effects of the dry and the rainy season on endocrine and physiologic profiles of goats in the Brazilian semi-arid region. Ital. J. Anim. Sci. 17, 454-461.

DOI: $10.1080 / 1828051 X .2017 .1393320$

SALIM ELSHEIKH, A., N. SALIM ELHAMMALI (2015): Semen quality of mature crossbred male goats during different seasons. IOSR J. Agric. Vet. Sci. Ver. II 8, 23192372.

DOI: $10.9790 / 2380-08920105$

SUHAIR, S. M., M. A. ABDALLA (2013): Effects of seasonal changes and shearing on thermoregulation, blood constituents and semen characteristics of desert rams (Ovis aries). Pakistan J. Biol. Sci. 16, 1884-1893.

DOI: $10.3923 /$ pjbs.2013.1884.1893

THOM, E. C. (1959): The disconfort index. Weatherwise 12, 57-59.

THOMAS, M., T. K. NEETHU, V. SEJIAN, A. MOHAMMED (2015). Heat tolerance in Attappaddy Black Does reared under hot humid tropical environment. J. Vet. Sci. Med. Diagnosis. 4, 1-5.

DOI: $10.4172 / 2325-9590.1000156$

WAGNER M. S., S. M., WAJNER, A. L. MAIA (2008): The role of thyroid hormone in testicular development and function. J. Endocrinol. 199, 351-365.

DOI: $10.1677 / \mathrm{JOE}-08-0218$

WANG, W., J. LUO, S. SUN, L. Xi, Q. GAO, A. HAILE, H. SHI, W. ZHANG, H. SHI (2015): The effect of season on spermatozoa motility, plasma membrane and acrosome integrity in fresh and frozen-thawed semen from Xinong Saanen bucks. Reprod. Domest. Anim. 50, 23-28.

DOI: $10.1111 /$ rda.12444

WINGFIELD, J. C., R. M. SAPOLSKY (2003): Reproduction and resistance to stress: when and how. J. Neuroendocrinol. $15,711-724$.

DOI: $10.1046 / \mathrm{j} .1365-2826.2003 .01033 . \mathrm{x}$ 
SALLES, M. G. F., A. M. VIANA NETO, M. F. VIEIRA NETO, I. C. S. RODRIGUES, D. R. DA ROCHA, P. T. DE SOUZA CARNEIRO, A. A. DE ARAÚJO: Utjecaj sezonskih promjena tropske klime na reprodukcijske pokazatelje i hormonski status jaraca sanske pasmine. Vet. arhiv 90, 235-242, 2020.

\section{SAŽETAK}

U ovom je radu istražen utjecaj različitih sezona (kišna, prijelaz iz kišne u suhu, suha, prijelaz iz suhe u kišnu) tijekom godine na reprodukcijski i endokrini status jaraca sanske pasmine uzgojenih u tropskoj klimi. Zabilježeni su podaci iz okoliša (temperatura i relativna vlažnost zraka) za vrijeme različitih sezona kako bi se izračunao indeks topline. Za ista su razdoblja procijenjeni reprodukcijski pokazatelji kako bi se istražile njihove sezonske varijacije u koju je svrhu od 9 jaraca sanske pasmine primjenom umjetne vagine, prikupljano sjeme dva puta mjesečno. Osim toga mjereni su obujam skrotuma, temperatura površine skrotuma te razina testosterona, trijodotironina (T3), tiroksina (T4) i kortizola u serumu. Klimatski uvjeti su utjecali na reprodukcijske pokazatelje, najviše za vrijeme suhog razdoblja, kad veće vrijednosti temperature okoliša smanjuju kvalitetu sjemena jaraca. Obujam i temperatura površine skrotuma, kao i serumska razina testosterona, u navedenoj sezoni su povećani. Zaključeno je da su sanski jarci uzgojeni u tropskoj klimi pod utjecajem toplinskog stresa, što se vidi iz sezonskih varijacija njihovih reprodukcijskih pokazatelja, pri čemu je kišna sezona najpovoljnija za reprodukciju.

Ključne riječi: jarci; reprodukcijski pokazatelji; toplinski stres; testosteron 